\title{
PENGALAMAN HIDUP SEORANG REMAJA PUTRI KORBAN TRAFFICKING DALAM BENTUK EKSPLOITASI SEKSUAL
}

\author{
Siti Zuliya Ningsih dan Satiningsih \\ Program Studi Psikologi Universitas Negeri Surabaya
}

\begin{abstract}
This study was aimed to understand a young girl experience as a victim of human trafficking. Data from the women and child protection center of Surabaya (Pusat Pelayanan Terpadu Perlindungan Perempuan dan Anak or PPT-P2A) had shown an increase in the number of trafficking victims from year to year. In 2010, there were 28 cases of adult victims and 21 cases of children victims. On April 2012 the cases of adult victims increased up to 45 cases, while children decreased to 13 cases. This study used a qualitative phenomenological approach. The participant was a victim of trafficking and was under the supervision of PPT- P2A Surabaya. Data was collected using a semi-structured interviews and analyzed using narrative analysis. The result of this study can be described into three categories, which were the life before becoming a victim, undesired job, and the life after becoming a victim. Since the mother passed away, she felt like there is no one cares about her anymore. The second was undesired job, which related to the participant's experience as a trafficking victim. The last theme was the participant's life after being a victim. In general, it could be concluded that participant experienced some psychological dynamics, such as negative selfconcept, low self esteem, andlearnedhelplessness.
\end{abstract}

Keywords: Psychological impact, young women, trafficking.

\begin{abstract}
Abstrak: Penelitian ini bertujuan untuk mengetahui pengalaman seorang remaja putri yang menjadi korban trafficking. Data Pusat Pelayanan Terpadu Perlindungan Perempuan dan Anak (PPT-P2A) Surabaya menunjukkan peningkatan jumlah korban trafficking dari tahun ke tahun. Tahun 2010 korban dewasa mencapai angka 28 orang, sedangkan anak-anak 21 orang. Tahun 2011 korban dewasa menjadi 34 dan anak-anak meningkat menjadi 36, data terbaru tahun 2012 bulan April korban dewasa meningkat menjadi 45 korban dan anak-anak menjadi 13 korban kejahatan trafficking. Penelitian ini menggunakan pendekatan kualitatif fenomenologis. Proses pengambilan data menggunakan teknik wawancara semi terstruktur. Data penelitian ini kemudian dianalisis menggunakan analisis naratif. Hasil dari penelitian berhasil mengidentifikasi beberapa sub-sub judul atau tema. Subjudul pertama yakni semenjak Ibu tiada yaitu kisah hidup partisipan sebelum menjadi korban trafficking, semenjak Ibunya meninggal, partisipan merasa tidak ada lagi yang peduli padanya. Tema atau sub judul kedua yakni pekerjaan yang tidak sesuai keinginan yaitu pengalaman partisipan selama menjadi korban trafficking. Tema ketiga, kehidupan setelah menjadi korban, yaitu pengalaman hidup partisipan setelah menjadi korban trafficking. Secara umum, kesimpulan dari penelitian ini adalah pertisipan mengalami beberapa fenomena psikologis yaitu konsep diri negatif, harga diri rendah, dan learned helplessness.
\end{abstract}

Kata kunci: Dampak psikologis, remaja putri, trafficking.

Saat ini kejahatan perdagangan manusia (human trafficking) di Indonesia terus mengalami peningkatan. Wartakota (2013) melaporkan bahwa berdasarkan data dari
United Nations Population Fund (UNFP), Indonesia saat ini berada di peringkat ke-2 sebagai negara yang paling banyak terjadi perdagangan manusia. Indonesia dicap 
sebagai pengirim, penampung dan sekaligus memproduksi aksi kejahatan ini. Berdasarkan data International Organization of Migration/IOM (dalam Hukumonline.com, 2012) dapat diketahui bahwa hingga April 2006, jumlah kasus perdagangan manusia di Indonesia mencapai 1.022 kasus dengan rincian 88,6 persen korbannya adalah perempuan, 52 persen dieksploitasi sebagai pekerja rumah tangga, dan 17,1 persen dipaksa melacur. Menurut Pusat Pelayanan Terpadu Perlindungan Perempuan dan Anak / PPT-P2A Surabaya (2012) terjadi peningkatan korban trafficking dari tahun ke tahun di Jawa Timur yaitu dari tahun 2010 korban dewasa mencapai angka 28 orang, sedangkan anak-anak 21 orang, tahun 2011 korban dewasa menjadi 34 dan anak-anak meningkat menjadi 36 , data terbaru tahun 2012 hingga bulan April korban dewasa meningkat menjadi 45 korban dan anak-anak menjadi 13 korban kejahatan trafficking.

Perserikatan Bangsa-Bangsa (PBB) (dalam Farhana, 2010: 20) mendefinisikan trafficking sebagai "perekrutan, pengiriman, pemindahan, penampungan, atau penerimaan seseorang, dengan ancaman, atau penggunaan kekerasan, atau bentuk-bentuk pemaksaan lain, penculikan, penipuan, kecurangan, penyalahgunaan kekuasaan atau posisi rentan, atau memberi atau menerima bayaran atau manfaat untuk memperoleh ijin dari orang yang mempunyai wewenang atas orang lain, untuk tujuan eksploitasi”. Dalam UU Nomor 21 Tahun 2007 Pasal 1 angka 7, eksploitasi didefinisikan sebagai "tindakan dengan atau tanpa persetujuan korban yang meliputi, tetapi tidak terbatas pada pelacuran, kerja atau pelayanan paksa, perbudakan atau praktik serupa perbudakan, penindasan, pemerasan, pemanfaatan fisik, seksual, organ reproduksi atau secara melawan hukum memindahkan atau mentransplantasi organ dan/atau jaringan tubuh, atau memanfaatkan tenaga atau kemampuan seseorang oleh pihak lain untuk mendapatkan keuntungan baik materiil maupun immaterial" (Farhana, 2010:25-26).

Perdagangan menusia telah ditetapkan sebagai kejahatan dalam hukum Indonesia yang secara eksplisit disebut dalam UU Nomor 21 Tahun 2007 pasal 2 (dalam Nasution, 2008) yang menyatakan bahwa: "Setiap orang yang melakukan perekrutan, pengangkutan, penampungan, pengiriman, pemindahan, atau penerimaan sesorang dengan ancaman, penggunaan kekerasan, penculikan, penyekapan, pemalsuan, penipuan, penyalahgunaan kekuasaan, atau posisi rentan, penjeratan utang atau memberi bayaran atau manfaat, walaupun memperoleh persetujuan dari orang yang memegang kendali atas orang lain untuk tujuan mengeksploitasi orang tersebut di wilayah negara Republik Indonesia, dipidana dengan pidana penjara paling singkat tiga tahun dan paling lama 15 tahun dan pidana denda paling sedikit Rp120.000.000,00 dan paling banyak Rp.600.000.000,00."

Maraknya kejahatan perdagangan manusia menurut Farhana (2010) diawali dengan semakin meningkatnya pencari kerja baik laki-laki maupun perempuan bahkan anak-anak untuk bermigrasi keluar daerah sampai ke luar negeri guna mencari pekerjaan. Kurangnya pendidikan dan keterbatasan informasi yang dimiliki menyebabkan mereka rentan terjebak dalam perdagangan manusia..

Salah satu hasil riset yang berkaitan dengan Perlindungan Hukum Terhadap Perempuan dan Anak Korban Perdagangan Manusia oleh Nasution (2008) menyimpulkan bahwa perlindungan hukum terhadap perempuan dan anak yang menjadi korban perdagangan manusia saat ini masih dirasakan kurang efektif. Hal ini terlihat dari sangat jarangnya pidana yang berat yang dijatuhkan oleh hakim terhadap pelaku perdagangan manusia. Belum adanya sanksi berupa ganti rugi terhadap pelaku perdagangan manusia juga menambah adanya rasa ketidakadilan 
pada korban perdagangan manusia yang telah menderita baik secara fisik, mental, maupun ekonomi.

Mayoritas korban kejahatan perdagangan manusia memang adalah perempuan dan anak. Seperti dilaporkan oleh Wartakota (2013), data kementerian Pemberdayaan Perempuan dan Perlindungan Anak Republik Indonesia menunjukkan sebesar 90,3 persen dari korban trafficking adalah perempuan. Dari prosentase tersebut, 23,6 persennya adalah anak-anak. Termasuk dalam korban ini adalah remaja yang menjadi objek eksploitasi seksual dalam bentuk pelacuran atau prostitusi.

Remaja yang memiliki pengalaman pernah menjadi korban kejahatan trafficking akan mengalami kerentanan dan tekanan emosional yang berat. Masa remaja menurut Santrock (2007:202) merupakan suatu masa di mana fluktuasi emosi berlangsung lebih sering. Remaja muda dapat merasa sebagai orang yang paling bahagia disuatu saat dan kemudian merasa sebagai orang yang malang di saat lain. Pengalaman dari lingkungan pada remaja dapat memberikan kontribusi yang lebih besar terhadap emosi remaja dibandingkan perubahan hormonal (Santrock, 2007).

Juwita (2008) menyimpulkan bahwa dampak psikologis yang dialami oleh Tenaga Kerja Wanita (TKW) dari Indonesia di Luar Negeri, termasuk di dalamnya adalah yang masih remaja, yang pernah menjadi korban kekerasan adalah cenderung cemas dan takut membuat kesalahan, sedih dan ketakutan jika teringat kejadian, cemas dan curiga terhadap orang yang baru dikenal, dan merasa malu terhadap tetangga. Perilaku para korban ini juga menunjukkan karakteristik seperti gagap jika ditanya, menangis, mengalami kesulitan tidur di malam hari, sering melamun, dan tidak berani bergaul.

Di antara dampak psikologis yang ditimbulkan oleh kejahatan perdagangan manusia menurut Gugus Tugas Nasional Pencegahan dan Penanganan Tindak Pidana Perdagangan Orang (2009) adalah korban akan mengalami kecemasan dengan tingkat depresi tertentu, perasaan bersalah, dan kehilangan kepercayaan diri untuk mampu hidup bersama masyarakat umum seperti remaja seusianya. Selain itu juga adan kekhawatiran akan masa depannya yang suram karena terputusnya pendidikan formal serta ketidak miliki kemampuan atau keterampilan yang dapat mendukung kehidupannya dimasa yang akan datang. Sedangkan dampak sosialnya adalah korban mengalami kesulitan dalam melakukan penyesuaian diri dengan lingkungan sosial.

Kemungkinan dampak lainnya adalah gejala stress pasca trauma yaitu gejala yang berhubungan dengan pengalaman traumatis selama menjadi korban perdagangan meliputi flashback, pikiran pelecehan yang terulang, mimpi buruk, menghindari setiap mengingat pengalaman traumatik mereka, reaksi emosional atau fisik tiba-tiba ketika teringat peristiwa traumatis, tidak bisa mengingat beberapa detail dari pengalaman mereka (Saniti, 2013). Dampak lainnya adalah rendahnya harga diri, dimana korban merasa tak berdaya, tidak mampu mengatasi pengalaman buruknya, kehilangan kontrol atau perasaan tidak berharga (Marliana, 2012). Fluktuasi harga diri selama masa remaja menurut Baldwin \& Hoffman (Santrock, 2007) berkaitan dengan peristiwaperistiwa hidup dan kohesivitas keluarga. Banyak penelitian menunjukkan bahwa anak muda yang memiliki harga diri rendah sebagian besar berasal dari keluarga atau kondisi yang banyak diwarnai konflik dan mereka sendiri mengalami kekerasan atau penolakan (Santrock, 2007).

Penderitaan emosional yang dialami remaja korban trafficking bisa menggganggu aktivitas sehari-harinya. Terutama, secara psikologis maupun sosial, remaja tersebut 
umumnya akan mengalami gangguan komunikasi dan penyesuaian diri dalam masyarakat. Remaja yang masih sekolah mungkin akan terhambat pendidikannya dan sulit untuk bersosialisasi dengan teman sebayanya. Karena itu, remaja yang menjadi korban trafficking cenderung akan mengalami perubahan tingkah laku yang dapat mengganggu fungsi perkembangannya dalam mencapai kematangan secara psikologis, seksual, sosial, maupun identitasnya.

Berdasarkan fenomena diatas, penelitian ini bertujuan untuk memahami pengalaman personal seorang remaja putri yang telah menjadi korban trafficking dalam bentuk eksploitasi seksual. Peneliti juga berupaya untuk mengungkap dampak psikologis yang dialami korban tersebut.

\section{METODE}

Penelitian ini menggunakan metode kualitatif fenomenologis yaitu jenis penelitian kualitatif yang melihat secara dekat bagaimana individu memahami dan menginterpretasi pengalaman-pengalaman subjektifnya (Emzir, 2010).

\section{Partisipan}

Subjek penelitian ini adalah remaja putri yang menjadi korban trafficking dalam bentuk eksploitasi seksual. Remaja putri tersebut berusia 18 tahun bernama Andin (nama samaran), anak terakhir dari sepuluh bersaudara yang memutuskan untuk bekerja demi memenuhi kebutuhan ekonomi keluarganya yang sulit. Penghasilan ayahnya sebagai petani tidak cukup untuk membiayai hidupnya dan saudara-saudaranya. Satu partisipan dalam penelitian kualitatif ini dapat diterima karena peneliti mengutamakan pendalaman tentang pengalaman dan interpretasi korban trafficking atas pengalamannya sebagai korban. Cara yang ditempuh peneliti untuk merekrut partisipan adalah dengan, pertama, meminta informasi dan mengajukan permohonan pada PPT (Pusat Pelayanan Terpadu) Jawa Timur untuk mendapatkan calon partisipan. Kemudahan dalam mendapat informasi dan bantuan dari lembaga tersebut dimungkinkan karena peneliti pertama sebelumnya telah melaksanakan magang selama sekitar satu bulan di lembaga tersebut. Setelah itu, tiga hari kemudian peneliti mendapatkan kabar dari key person dari pihak PPT tentang kesediannya untuk membantu. Setelah dua bulan peneliti pertama dihubungi oleh key person PPT untuk dipertemukan dengan seorang calon partisipan. Dalam pertemuan tersebut peneliti menjelaskan tujuan penelitian yang akan dilakukan, dan akhirnya mendapat persetujuan dari partisipan tersebut untuk melakukan wawancara tatap muka.

\section{Teknik Pengumpulan Data}

Teknik pengumpulan data yang digunakan dalam penelitian ini adalah wawancara mendalam semi-terstruktur dengan menggunakan pedoman wawancara yang tidak diikuti secara ketat. Pedoman wawancara berisi pertanyaan-pertanyaan tentang data demografis mengenai data diri partisipan, pengalaman masa kecil, kisah sebelum kejadian, peristiwa selama menjadi korban, dan kehidupan setelah selamat dari kejatahan trafficking. Proses pengambilan data dilakukan dengan didahului pembangun rapport selama kurun waktu tiga minggu. Wawancara dilakukan dua kali dalam waktu yang berbeda dan berlangsung antara 45-60 menit tanpa kehadiran pihak ketiga. Wawancara direkam menggunakan bantuan alat smartphone.

\section{Teknik Analisis Data}

Penelitian ini menggunakan teknik analisis naratif. Murray (2009) menyatakan 
bahwa sumber utama material bagi peneliti yang menggunakan analisis naratif adalah hasil wawancara. Tidak seperti wawancara terstruktur yang tradisional, yang memiliki rangkaian terperinci mengenai pertanyaan yang harus dijawab, wawancara naratif dibuat untuk menciptakan kesempatan bagi partisipan untuk memberikan narasi terperinci mengenai suatu pengalaman. Menurut Flick (dalam Smith, 2009) narasi bukan sekedar kisah kehidupan (life-story) dalam artian umum, melainkan juga kisah-kisah tentang pengalaman, terutama permasalahan hidup sehari-hari. Langkah pertama analisis adalah dengan cara mentranskrip data hasil wawancara. Selanjutnya, peneliti melakukan proses pembacaan secara ketat untuk memperoleh sub-sub judul atau tema untuk menangkap makna menyeluruh dari narasi yang ada. Langkah selanjutnya adalah mengkaitkan narasi dengan literatur teoritis yang lebih luas yang dapat digunakan untuk menginterpretasi kisah yang muncul.

\section{HASIL PENELITIAN}

Penelitian ini berhasil mengindentifikasi pengalaman subjek meliputi kisah hidup subjek sebelum menjadi korban trafficking, pengalaman selama menjadi korban, dan kehidupan setelah menjadi korban.

\section{Sebelum menjadi Korban}

Andin merasakan perubahan hidup semenjak Ibunya meninggal, ia merasa tidak ada anggota keluarganya lagi yang peduli padanya. Andin merasa kehilangan figur yang selalu memanjakkannya. Kutipan Dibawah menunjukkan kekecewaan Andin terhadap keluarganya.

\footnotetext{
"dulu waktu ibu masih hidup, (ibu) suka manjain aku. Sepeninggal ibu aku gak onok seng
}

\section{ngreken (keluarga tidak ada yang peduli)"}

Andin ditinggal ibunya sejak umur 12 tahun, waktu itu ia masih duduk dikelas 5 Sekolah Dasar (SD). Andin merasa semenjak Ibunya tidak ada, kakaknya kerap marah dan tidak segan untuk memukulinya, Andin menggambarkan keluarganya tidak berlaku adil padanya dan membuat Andin tidak betah di rumah.

\footnotetext{
"keluargaku pilih kasih, politik sama aku, iri-iri, sejenis itulah, makanya aku sering keluar, keluar malam. Waktu aku di rumah, sering dimarahin kakakku cowok, dipukulin, dimarahin terus. Jadi berontak"
}

Hubungan Andin dengan saudarasaudaranya, terutama kakak laki-lakinya, tidak harmonis. Dari ceritanya dapat diketahui bahwa ia pernah menjadi korban kekerasan dari kakak laki-lakinya. Karena keadaan keluarganya yang demikian, ia mengaku sering keluar malam sebagai bentuk pelampiasan. Atas keinginan kakak tertuanya yang tinggal di Mojokerto, Andin yang masih duduk di bangku Sekolah Menengah Pertama (SMP) memutuskan untuk tinggal bersama keluarga kakak laki-lakinya itu dengan harapan ia dapat memperbaiki kehidupannya. Penghasilan ayahnya sebagai petani memang tidak dapat menutupi kebutuhan hidupnya dan sebagai seorang remaja yang masih bersekolah.

“akhire aku dikongkon melok cacakku,
cacakku ngomong ngene"wes melu aku ae"
ponakanku juga, adikku, ngrayu untuk ikut
sama mereka, akhire aku melok mas, tapi
tetap Ayah nggaktega soale Ayah udah tahu
sifatnya keluargaku tapi aku maksa untuk
ikut masku” (akhirnya aku disuruh ikut
kakakku, kakakku bicara seperti ini "ya
sudah ikut aku saja” adik keponakanku,
anak dari kakaku, juga merayu agar ikut
sama mereka. Akhirnya aku ikut kakak, tapi
tetap Ayah tidak tega, soalnya Ayah sudah
tahu sifatnya keluarga kakakku, tapi aku
memaksa untukikut dengannya).


Cerita di atas menunjukkan bahwa keputusan pindah ke rumah kakaknya bukan merupkan keputusan yang menyenangkan bagi Andin karena kesadaran bahwa bahkan ayahnya sudah tahu "sifat" kakaknya. Penekanan pada sifat kakaknya yang tidak diinginkan Andin, bisa dianggap sebagai peneguhan atas pengalaman tidak menyenangkan selama tinggal dengan keluarga kakaknya tersebut. Andin merasa tinggal dengan keluarga kakaknya tidak membuat hidupnya menjadi lebih baik. Ia merasa kakaknya berlaku tidak adil padanya.

\begin{abstract}
"Aku iri sama ponakanku, adikku (ponakan) suka diturutin kalau minta apa-apa, kakakku pilih kasih. Aku nggak salah, tapi di mata mereka aku salah. Hidupku dari dulu mesti dibuat kalah-kalahan sama keluargaku."
\end{abstract}

Ia merasa cemburu dengan adik keponakannya, yang adalah anak kandung kakaknya yang dia ikuti, yang lebih mudah dikabulkan keinginan-keinginannya. Ia juga merasa sebagai anak yang diabaikan dalam keluarga besarnya.

Di sekolah, Andin juga menggambarkan teman-temannya sebagai teman yang tidak baik, teman yang selalu memanfaatkan dirinya karena mengetahui Andin mendapatkan warisan dari almarhumah Ibunya.

"karena tahu kalau aku dapat warisan, uangnya banyak. Dari kelas satu sampai lulus itu (aku) nggak punya teman yang baik, mereka sering manfaatin aku"

Kehidupan di sekolah akhirnya membuatnya tidak nyaman. Ia mengingat dirinya di masa sekolah itu sebagai orang yang lemah.

\footnotetext{
"Aku dibuat suruh-suruhan lah, kan aku orangnya lemah sih, dulu aku sering difitnah sama keluargaku, ya pernah. Aku merasa Tuhan tidak adil padaku, kenapa aku yang mengalami semua ini”.
}

Masalah di sekolah maupun di rumah membuat Andin menyalahkan Tuhan. Ia bercerita tentang perasaan tersebut sambil menarik nafas dan meneteskan air mata. Ketika peneliti bertanya padanya tentang bagaimana ia sendiri memandang dirinya, ia berkata:

"aku orangnya menyenangkan, sama orang juga
baik, tapi ya gampang ditipu orang, aku itu jiwa
penolong, sama temen juga sering bantu. Sama
orang lain itu nggak tegaan, selalu mengalah"

Cara Andin menggambarkan dirinya seperti di atas bisa dibaca sebagai upaya perlawanannya dan sekaligus rasionalisasi atas kesadarannya sendiri bahwa ia adalah orang yang lemah dan tidak bisa membela diri. Karena persepsi dan perasaan tersebut, Andin mempunyai keinginan untuk keluar dari rumah keluarga dan sekolahnya untuk bekerja agar bisa mandiri. Niat itu sempat tertunda karena setelah lulus SMP ia melanjutkan ke Sekolah Menengah Kejuruan (SMK) di Mojokerto. Namun, karena merasa tidak ada perubahan dalam hidupnya, sebelum menyelesaikan SMK, Andin akhirnya memutuskan keluar dari rumah kakaknya dan dari sekolahnya.

\section{Selama menjadi korban}

Andin meninggalkan rumah kakak lakilakinya dan memutuskan untuk mencari pekerjaan. Ia meminta bantuan teman lamanya di Sidoarjo. Ketika Andin mendatangi teman tersebut ternyata sudah tidak ada lowongan pekerjaan. Ia hampir putus asa, namun di tempat kos temannya, Bonita (nama samaran), terdapat dua orang yang menawarkan pekerjaan di Kalimantan. Ketika teman Bonita menawarkan pekerjaan padanya, yang tertarik justru Andin. Andin menceritakan awal mula ia memutuskan pergi ke Kalimantan dalam kutipan wawancara sebagai berikut: 
"pikirku kesempatan, trus aku ngene "aku po'o melok, daripada aku nganggur" trus arek iku ngomong "temen ta?". trus pikirku yo pokoe kerjo golek duwek dewe, iso tuku motor dewe, wes pikiranku yo mek iku tok, gak lain". (saya pikir itu kesempatan, makanya saya ajukan diri, "aku ikut ya, daripada aku nganggur" kemudian orang tersebut menjawab, "bener nih?". Saya waktu itu berpikirnya pokoknya bekerja mencari uang sendiri, bisa beli motor sendiri, ya sudah pikiranku ya hanya itu, tidak ada yang lain)

Bonita (teman Andin) sempat khawatir dan mencoba mengingatkan Andin yang pada saat itu langsung menyetujui pekerjaan di Kalimantan tersebut tanpa persiapan. Pada saat itu Andin merasa tidak perlu ada yang dikhawatirkan karena ia sudah bertekad untuk membiayai kebutuhan hidupnya sendiri. Andin menceritakan keadaan pada saat itu:

\begin{abstract}
"temenku sempet takok "gak popo a kerjo na Kalimantan?”,aku njawab, gak popo digawe sandangan ae, kamu gak melok ta?, gak wes aku nak kene ae gak iso ado karo arek-arek. Yowes akhire aku budal" (temanku sempat tanya "apa tidak masalah kerja di Kalimantan?", aku menjawab tidak apa-apa, untuk membeli sandang pangan saja. kamu tidak ikut? Temannya jawab: "tidak, aku disini saja tidak bisa jauh sama teman-teman di sini. Ya sudah akhirnya aku pergi sendirian).
\end{abstract}

Andin langsung diantar oleh penawar kerja ke rumah Mama $\mathrm{T}$ (orang yang mengirimkan Andin ke Kalimantan). Andin tidak lantas langsung berangkat, ia pulang lagi ke kota Mojokerto untuk mengambil perlengkapannya yang ada di rumah kakaknya. Mama T yang mengantarkannya.

\footnotetext{
"Habis itu aku dijak sama dua orang ke rumaha mama, aku mintak tolong sama mama $\mathrm{T}$ "Ma, barang-barangku dorong (belum) diambil, yo opo iki? (bagaimana ini?)". Habis itu mama ngantarin aku ke Mojokerto ngambil barangbarangku semua naik motor."
}

Keesokan harinya Andin berangkat menuju bandara Juanda diantarkan oleh teman Mama Tobing. Setelah menunggu semua urusan tiket selesai, Andin pun di berangkatkan ke Kalimantan pukul 11 siang. Setelah dua jam perjalanan, Andin sampai di Balikpapan, Kalimantan dan di jemput oleh seorang laki-laki. Andin menceritakan lakilaki tersebut sebagai putra dari Mama $\mathrm{T}$. Setelah menyebrangi laut, perjalanan dilanjutkan ke Tonajam dengan lama perjalanan setengah hari sampai tempat tujuan yaitu kawasan Rambutan (Kalimantan). Andin menceritakan keadaan saat itu dalam kutipan wawancara berikut:

\begin{abstract}
"Sampe juanda jam 9, nunggu tiket-tiketnya, jam 11 baru brangkat, sampe di Kalimantan jam 12, perjalanan 1 jam atau 2 jam. Sampek Kalimantan aku dijemput sama seorang cowok, anaknya mama $\mathrm{T}$, dijemput di Balikpapan Kalimantan sana, habis dijemput, menyebrang laut, naik kapal, habis itu naik taksi, perjalanan melewati Tonajam Perjalanannya setengah hari sampe Rambutan"
\end{abstract}

Ketika pewawancara bertanya apakah Andin tidak merasa curiga dengan situasi saat itu, Andin menjawab selama perjalanan Andin tidak merasakan perasaan yang aneh atau merasa curiga, namun dalam perjalanan Andin sempat ragu tentang pekerjaannya nanti. Namun, pikiran itu hilang ketika lakilaki yang bersamanya mengatakan bahwa pekerjaannya hanya sebagai pelayan warung kopi. Andin bercerita sebagai berikut:

\begin{abstract}
"Aku nggak merasa curiga sama sekali, perjalanan 4 jam baru aku mikir, cuma langsung dibilangin sama cowok tadi, "kerjanya itu ya di warung kopi aja, kamu sudah tahu kan kerjanya gimana”, trus aku tanya balik, "emang kerjanya gimana sih mas?"Wes (ya) kayak gitu warung kopi, wes (ya) cuma itu aja kok. Bayanganku $i k u$ (itu), masa kerja kayak gini, kayak gini, tapi ya wes lah (ya udah)..."
\end{abstract}

Sesampainya di Rambutan, Andin menggambarkan situasi tempat yang didatanginya adalah warung-warung sepi di 
pinggiran hutan dan banyak perempuan cantik yang berdandan menor. Saat itu ia tidak menduga sama sekali.

\begin{abstract}
"habis itu berangkat sampai Rambutan, daerahnya itu sepi, kayak (seperti) hutan, kayak rumah-rumah kayak daerah Dolly (kawasan pelacuran di Surabaya), tapi itu warung-warung kopi. Aku kaget, "lho kok kayak gini ya, banyak cewek yang dandannya menor-menor, cantikcantik".
\end{abstract}

Namun Andin hanya mengikuti saja ketika diajak masuk ke sebuah warung yang nantinya menjadi tempat kerjanya. Di sana ia bertemu dengan pemilik warung yang biasa dipanggil "Mami" dan nantinya menjadi atasan Andin. Mami menyambut Andin dengan hangat dan ramah. Ia dipeluk dan disuguhi minuman. Andin diberitahu bahwa minuman itu sudah diberi mantra untuk menolak bala.

\footnotetext{
"Sampai warung saya lewat belakang terus ketemu sama Mami, juragan saya, kami berpelukan, terus aku dikasih minum buat nggak ada balak gitu katanya, semacam air putih tapi dikasih mantra-mantra nggak tau lah itu, tak minum aja, mungkin buat obat istirahat buat tenangin pikiran atau apa"
}

Selang beberapa menit Andin keluar untuk melihat keadaan luar sambil dudukduduk santai. Meski ia agak heran melihat banyak laki-laki pada duduk di warung tersebut, Andin tidak merasa curiga. Akhirnya Andin mulai bekerja di warung itu sebagai pelayan. Tidak ada pembicaraan dengan Mami tentang gaji yang akan ia terima. Namun Andin berpegang pada janji orang yang mengirimkannya ke Kalimantan bahwa ia akan digaji 10 juta per bulan meski ia merasa ragu.

\footnotetext{
"aku bingung, wong Cuma bekerja ginian kok gajinya segitu, tapi tidak apa-apa lah yang penting bekerja"
}

Ia bangun jam 4 atau 5 pagi untuk membantu Mami memasak dan mencuci piring. Warung kopi beroperasi hampir 24 jam, mulai buka jam 7 pagi dan tutup jam 3 pagi. Dua hari setelah kedatangannya Andin mendengar pembicaraan seorang pelanggan. Ia merasa pelanggan tersebut sedang membicarakan atau sedang menawarnya. Pelanggan tersebut menawari Andin untuk masuk kamar. Ia mulai curiga dengan pekerjaannya yang sesungguhnya dan menanyakannya pada Mami. Ia memperoleh jawaban bahwa pekerjaannya adalah untuk melayani tamu. Andin mulai mengerti maksud Maminya.

\begin{abstract}
"Pikiranku kayak gini, oh ternyata aku kerjaannya gini ya. Terus aku kebelakang, tanya Mami, "Mi, emang aku kerja apa sih?". Dia jawab, "Ya nglayanin tamu itu lho." Ya Allah ternyata aku kerja ginian, aku gowo ruko gak pernah dipakek, ado-ado kerjo ternyata kerjo ginian (saya bawa mukena untuk sholat akhirnya tidak pernah saya gunakan, jauh-jauh kerja ternyata bekerja begini). Aku merasa takut pada mami, kerja ikut orang, tidak tahu sama sekali daerah situ, jadi terpaksa aku melayaninya.Takut, sama mami selalu diawasin. Lagian tidak tahu sama sekali daerah situ, takut diapa-apain “.
\end{abstract}

Andin merasa tak berdaya karena jauh dari rumah dan merasa mempunyai tanggung jawab bekerja ikut orang lain. Andin memutuskan berangkat ke Kalimantan tanpa memberitahu pada keluarganya. Semua biaya pemberangkatan ditanggung oleh orang yang mengirimkannya. Andin merasa tidak bisa berbuat apa-apa. Ia takut akan terjadi sesuatu yang tidak ia inginkan jika ia tidak menuruti keinginan Mami dan pelanggan karena ia merasa sendirian di tempat asing yang jauh. Andin tidak diperbolehkan keluar dari kawasan warung-warung daerah Rambutan tersebut dan tidak diperbolehkan memegang ponsel. Semua kebutuhan Andin sudah dipenuhi oleh Maminya.

Maka, cara Andin untuk menghindar adalah dengan mematok harga tinggi ketika 
ada yang menawarnya. Namun pada akhirnya ada pelanggan yang siap memenuhi permintannya. Andin sadar bahwa ia tidak lagi bisa menolak. Andin terpaksa memenuhi perintah Mami untuk masuk kamar dan melayani pelanggan tersebut. Ia menghibur diri dengan membayangkan bahwa ia akan segera mendapat banyak uang untuk memenuhi keperluannya.

\begin{abstract}
Terpaksa gelem. Udah bingung karepe dewe. Yo opo carane iso cepet nduwe duwek. Kerjo temen, iso ngmpulno duwek seng akeh, opo seng dipingini iso keturutan kabe. Terpaksa, asline kan gak gelem dibawa orang, gak wani ngalawan, kudu nurut. (Terpaksa mau. Sudah bingung sendiri. Bagaimana caranya bisa cepat punya uang. Kerja yang benar. Dapat mengumpulkan uang banyak, apa yang diinginkan bisa terpenuhi semua. Terpaksa, awalnya kan tidak mau dibawa orang ke kamar, tidak berani melawan, harus menurut).
\end{abstract}

Andin mengungkapkan bahwa ia harus melayani empat sampai lima pelanggan dalam satu hari. Setelah mengetahui ternyata pekerjaannya seperti itu ia merasa sakit hati dan ingin pulang. Ia mengalami lima hari yang berat tersebut sebelum akhirnya diselamatkan.

"perasaanku sakit, pingin pulang, gak kerasan. Aku nemenin cowok itu cuma lima hari, tapi sehari itu empat kali sampai lima kali. Aku pingin pulang, aku dikamar terus"

Ketika dipaksa keluar kamar, ia berusaha tidak peduli dengan orang di sekitarnya. Kepada pelanggan yang menyukainya, ia katakan bahwa ia tidak menyukai pekerjaannya dan ingin pulang. Suatu hari ada seorang laki-laki (bernama Aki-nama samaran) mendatanginya dan berniat menolongnya. Ia adalah seorang anggota kepolisian setempat dan mendapat informasi dari temannya yang pelanggan warung bahwa Andin ingin keluar dari tempat itu.

\begin{abstract}
“aku bilang pada $\mathrm{P}$, orang yang sempet suka aku, tapi kuanggap kakak, aku bilang aku pingin pulang. Tiba-tiba aku diajak kenalan sama Aki, seorang polisi. Dia itu niat bantuin aku, aku disuruh sabar"
\end{abstract}

Andin menceritakan bahwa keesokan harinya Mami pergi ke Balikpapan untuk berlibur. Kesempatan ini digunakan Andin untuk mencari cara menghubungi Aki. Andin berhasil menghubunginya dan minta dijemput setelah dipinjami ponsel oleh P. Berikut cerita Andin tentang peristiwa tersebut:

\begin{abstract}
"besoknya mami pergi ke Balikpapan, katanya liburan. Lha, aku di warung tinggal cuma orang tiga, aku nggak nglayanin tamu, aku ngecewain tamu, kan aku udah males kerja kayak gitu, Malamnya Aki sama teman-temannya datang untuk ngluarin saya dari situ, akhirnya aku keluar, dibantuin sama Aki. Aku ditanyain, "kamu bener-bener ingin keluar dari sini?" Terus habis itu aku keluar, temenku nggak mau keluar, sempat minta maaf sama aku. Aku pulang sama Aki, dalam perjalanan Aki itu bilang kayak gini, "Udah lega kan, udah bisa keluar dari warung itu?" Aku bilang, "Iya, alhamdulillah". "Kamu itu sebenarnya orangnya baik, kok gampangnya dibohongin sama orang" Aku tanya "Emangnya kenapa Ki?" Kamu nggak nyadar kalau kamu itu... wes besok aja."
\end{abstract}

Dengan bantuan polisi setempat, Andin akhirnya dapat dipulangkan ke Surabaya. Andin baru memahami maksud Aki ketika sampai di Surabaya bahwa ia adalah korban perdagangan manusia (human trafficking). Ia diantarkan polisi ke PPT-P2A (Pusat Pelayanan Terpadu Perlindungan Perempuan dan Anak) Surabaya untuk mendapatkan pendampingan.

\section{Kehidupan Sebagai Mantan Korban Trafficking}

Saat ini kesibukan sehari-hari Andin adalah bekerja. Ia menjadi buruh di sebuah pabrik di Surabaya. Ia tidak melanjutkan 
sekolahnya yang dulu putus di tengah jalan. Andin bekerja sesuai shift yang telah ditentukan oleh perusahaan. Andin bercerita sebagai berikut:

\begin{abstract}
"Pagi kerja, kalau masuk pagi sampai jam 3, lalu bersih-bersih rumah, mandi, nonton TV. Kalau maghrib shalat ya shalat, kan jarang shalatnya tuh. Terus tidur sampe pagi, itu aja kerjaanku. Kalau berangkat sore, pagi udah bersih-bersih rumah, atau pingin masak-masak atau apa. Jam 8 atau jam 9 aku tidur lagi sampek jam 12 (siang). Jam 1 (siang) berangkat kerja sampek jam 9 (malam) terus nongkrong sama anak kerjaan, jam 11 sampai jam 12 (malam), pulang tidur, kadang kalau kemalaman aku tidur dikosnya temenku yang dekat pabrik."
\end{abstract}

Andin mengungkapkan bahwa ia merasa sedih apabila mengingat masa lalunya.

\begin{abstract}
"sebenarnya saya kan susah banget cerita ini, saya berusaha menjadi lebih baik, ini kan tertutup ceritanya. Ya, sungguh sakit menjadi korban trafficking. Perasaanku sih gimana ya... ya sakit aja mbak. Ya sakit mengenang semua itu".
\end{abstract}

Andin juga takut kisahnya diketahui orang. Andin mengalami ketakutan sendiri terhadap orang yang baru ia kenal, ia mengungkapkan ada perasaan takut karena tidak ingin orang mengetahui kisahnya.

\begin{abstract}
"Ya agak takut jujur (pernah menjadi korban trafficking). Di saat aku udah ngungkapin semua perasaanku semua, takutnya di sisi lain orang lain (jadi) tahu (kisahku)... Ya udah lah, jujur dari awal aku takut, kalau ada orang lain tahu.
\end{abstract}

Ia mengaku jika ada orang lain tahu bahwa ia pernah menjadi korban trafficking, ia akan merasa sakit dan terhina.

"jujur sih, sakit, sakit banget, merasa terhina, tapi disisi lain ya udah lah kan udah masa lalu dan udah nggak penting bagi saya dan menjadi pelajaran bagi saya itu dulu ya dulu, sekarang ya sekarang."
Tapi ia menyadari bahwa ia hanya bisa menerima masa lalunya itu. Ia berusaha melupakannya dan berharap bisa mengambil pelajaran yang berharga darinya. Salah satu cara untuk melupakan masa lalunya menjadi korban trafficking adalah dengan memfokuskan diri untuk bekerja dan bergaul dengan teman-teman kerjanya.

\begin{abstract}
"Kerja, dan cuma fokus kerja. Kadang kalau lagi libur kerja, cuma main sama teman-teman, kumpul-kumpul, cari hiburan"

Sakit ngrasain semua ini, sakit hati dan sakit hati lah. untuk menghilangkan semua itu, saya hidup yang baru, menjadi lebih baik, cari hiburan, intinya ya cari hiburan gitu aja, cari teman buat menghibur."
\end{abstract}

Andin menceritakan bahwa tidak semua temannya memiliki kebiasaan baik, namun ia yakin memiliki kontrol diri hingga tidak akan ikut-ikutan. Yang penting baginya adalah bersama mereka, ia bisa menghibur diri.

\begin{abstract}
"Kalau ngumpul-ngumpu di kos, terus minumminum, minuman keras atau pake barang terlarang. Terus ada juga yang nawarin aku pake gitu, aku nggak mau, aku bilang " $u d a h$ cukup, aku nggak mau, kalau kamu ngajak aku, nggak usah" Akhirnya ya bisa ngerti itu anak-anak. Terus ngajak karaoke bareng, ada yang minumminum, tapi aku Cuma nyanyi, nggak ikutan (minum)."
\end{abstract}

Andin juga mengungkapkan ada perubahan kebiasaan sehari-hari setelah ia menjadi korban trafficking.

\begin{abstract}
"Semenjak aku jadi korban aku jarang shalat, jarang ngaji terus sekarang itu ya jarang di rumah. Dulu itu waktu sebelum menjadi korban, aku sering ngaji, bersih-bersih rumah, jarang keluar, tepat waktu kalau pulang. Semenjak semuanya (kejadian) itu, tubuh mau hancur saya itu, sering dihantui bayang-bayang merasa bersalah. Tapi di sisi lain aku itu sedih, kenapa sih aku gini menjalani sendirian.”
\end{abstract}

Andin merasa sering dihantui perasaan bersalah. Ia juga merasa sedih dan merasa 
menanggung bebannya seorang diri. Ia merasa belum bisa memperbaiki hubungannya dengan Tuhan karena merasa malu atas dosanya.

\begin{abstract}
"Aku itu pingin shalat, tapi aku malu sama Tuhan. Malunya itu gimana ya, malunya itu udah kena dosa banyak, udah kena gitu (korban trafficking), pingin ndeketin diri lagi (pada Tuhan), merasa malu udah nggak pantes jadi umat-NYA. Jadi aku nggak pantes, tapi di sisi lain hatiku pingin banget shalat tapi susah banget."
\end{abstract}

Perasaan bahwa dirinya penuh dosa dan tidak berharga di hadapan Tuhan, membuatnya masih terus mencoba menghibur diri dengan bergaul bersama teman-teman kerjanya. Meskipun demikian, ia sesungguhnya tidak menginginkan kehidupan semacam itu.

\footnotetext{
"Pendapat aku sih, kehidupanku, menjalani semua itu salah. Ya, bergaul sama orang yang nggak penting, contohnya kayak nongkrong malam, main-main gitu aja, lihat balapan, bagiku itu nggak penting. Tapi gimana ya, aku itu mau (bersama mereka), padahal aku itu tahu kalau nggak ada untungnya. Pingin di rumah, aku itu berusaha menjauhi (mereka), tapi temenku itu pingin ngajak aja. Di sisi lain aku pingin ngomong (tidak mau), (tapi) aku itu takut, takut dijauhin, (dianggap) sombong..."
}

Saat ini Andin mengaku masih belum siap meninggalkan kebiasaannya. Tapi ia mengungkapkan keinginannya untuk berubah. Andin berkata apabila suatu saat ia berhasil berubah, ia sudah tidak peduli apa yang akan dikatakan orang maupun temannya. Andin tidak ingin kembali mengecewakan orang tua seperti dulu. Ia merasa sudah lelah. Ia hanya ingin keluarga atau orang tuanya dipandang baik oleh masyarakat. Keinginan Andin tersebut terungkap dalam kutipan wawancara berikut ini.

\footnotetext{
"kalau aku sudah berubah, apa kata orang nggak penting, peduli sama orang lain percuma, yang
}

penting kan saya nggak gitu (melakukan hal buruk), ... aku nggak pingin ngecewain orang tua lagi, udah cukup aku ngecewain (mereka karena) masa laluku. Aku udah capek, udah nggak penting bagi saya, nggak peduli sama orang lain. Toh, mereka nggak ngerawat aku kan, aku nggak peduli dikatain nakal, aku pingin orang tuaku atau keluargaku dipandang baik."

\section{PEMBAHASAN}

Berdasarkan hasil penelitian yang telah diuraikan di atas, dapat diketahui bagaimana hingga akhirnya Andin terjerat menjadi korban trafficking dalam bentuk eksploitasi seksual dan bagaimana ia menjalani kehidupannya yang singkat sebagai korban. Paparan hasil penelitian di atas juga dapat menunjukkan bagaimana pengalaman singkat sebagai korban itu telah menimbulkan dampak psikologis yang tak mudah diatasi.

Saat masih berumur 12 tahun, Andin telah kehilangan sosok Ibu yang menjadi pelindungnya. Sejak saat itu, ia merasa tidak ada lagi yang memperhatikannya. Bahkan ia sempat menjadi korban kekerasan fisik dari kakaknya sendiri. Andin mengalami sebuah attachment (kelekatan emosional) yang kurang kokoh dengan orang tua maupun anggota keluarganya yang lain. Padahal attachment atau ikatan emosional yang kokoh dengan orang tua, menurut Santrock (1995), dapat menyangga remaja dari kecemasan dan potensi-potensi perasaan depresi atau tekanan emosional yang berkaitan dengan transisi dari masa anak-anak menuju masa dewasa. Andin menggambarkan dirinya sebagai orang yang selalu dinomorduakan oleh keluarganya sendiri. Ia juga merasa keluarganya selalu menyalahkan dirinya. Tidak hanya itu, ia juga merasa teman-teman sekolahnya selalu memanfaatkannya. Ia merasa lemah dan tidak bisa membela diri.

Cara pandang atas dirinya yang demikian tampaknya menujukkan bahwa konsep dirinya cenderung negatif. Salah satu 
tanda konsep diri negatif menurut Wiliam \& Philip (dalam Rakhmat, 2009) adalah cenderung merasa tidak disenangi orang lain. Ia merasa tidak diperhatikan. Karena itulah ia bereaksi terhadap orang lain sebagai lawan, sehingga tidak dapat melahirkan kehangatan dan keakraban persahabatan. Salah satu faktor yang mempengaruhi konsep diri adalah orang lain. Ketika seseorang masih kecil, orang lain adalah orang tua kita, saudara-saudara kita, dan orang yang tinggal satu rumah dengan kita. Basis emosional positif yang tidak diperoleh Andin dari keluarga besarnya dapat dianggap sebagai salah satu penentu konsep dirinya yang cenderung negatif tersebut.

Konsep diri yang negatif inilah yang pada akhirnya mempengaruhi harga dirinya. Harga diri pada remaja memang cenderung fluktuatif. Menurut Baldwin \& Hoffman (dalam Santrock, 2007:186), fluktuasi harga diri selama masa remaja ini sering berkaitan dengan peristiwa-peristiwa hidup dan kohesivitas keluarga. Remaja yang memiliki harga diri rendah pada umumnya berasal dari keluarga atau situasi sosial lainnya yang banyak diwarnai konflik, dan mereka sendiri mengalami kekerasan atau penolakan dan kurang mendapatkan dukungan emosional (Santrock, 2007). Andin memandang keberadaannya dalam keluarga sebagai anak yang terabaikan dan tidak dihargai sesuai dengan keinginannya. Ketidakmampuan Andin dalam menerima kenyataan bahwa orang tua tentu saja lebih menyayangi anak kandungnya sendiri, seperti tersirat dalam ceritanya tentang kakaknya yang lebih memanjakan anaknya ketimbang dirinya, menunjukkan bahwa ia mengidamkan figur pemberi kasih sayang seperti almarhum ibunya. Bapak dan kakaknya tidak dapat memenuhi harapannya akan figur tersebut. Perasaan semacam itulah yang membuat Andin merasa sepeninggal ibunya, hidupnya dalam keluarga kakaknya "dibuat kalahkalahan". Dengan menggunakan frase tersebut, Andin tampaknya memposisikan dirinya sebagai orang yang lemah dan tidak memiliki figur pelindung yang membelanya.

Situasi yang tidak menyenangkan di rumah kakaknya di mana ia dititipkan bapaknya, dan ketiadaan teman dekat di sekolah, membuat Andin memutuskan pergi dari rumah dan sekolahnya. Pada situasi ketika ia sedang 'lari' dari sesuatu untuk mendapatkan "tempat perlindungan baru" di luar keluarganya, tidaklah mengherankan jika ia mudah percaya pada pertolongan orang lain. Ia dengan mudah menerima tawaran pekerjaan di Kalimantan dengan iming-iming gaji 10 juta rupiah per bulan. Jumlah tersebut sesungguhnya tidak masuk akal untuk anak yang belum lulus SMK tersebut. Namun, upaya untuk melepaskan diri dari ketergantungan terhadap keluarga dan untuk segera dapat memenuhi segala keinginan masa remajanya sendiri, membuat Andin segera menyambut tawaran itu tanpa berpikir panjang.

Ketika akhirnya ia menyadari pekerjaanya adalah sebagai pekerja seks, ia sudah merasa tak berdaya. Ia merasa sendiri di tempat asing dan menanggung hutang biaya perjalanannya dari Surabaya dan kebutuhannya sehari-hari pada sang Mami. Andin tidak lagi memiliki kemampuan untuk mengendalikan lingkungan pada saat itu sehingga ia menyerah dengan kejadian yang menimpanya. Fenomena psikologis yang dialami Andin dapat dikaitkan dengan konsep learned helplessness. Menurut Peterson, Maier \& Seligman (dalam Sitompul, 2009) learned helplessness adalah suatu keadaan ketika pengalaman atas kejadian yang tidak dapat dikontrol mengarah pada harapan bahwa kejadian-kejadian di masa mendatang akan tidak dapat dikontrol juga. Abraham dkk. (dalam Sitompul, 2009) menambahkan bahwa learned helplessness adalah ketidakmampuan individu untuk mengendalikan lingkungannya yang akan membimbingnya pada sikap 
menyerah atau putus asa.

Pemahaman Andin atas perjalanan hidupnya bahwa ia menjadi orang yang mudah dimanfaatkan teman-teman sekolahnya dan anggota keluarga besarnya sepanjang hidupnya sendiri telah membentuk pribadi Andin yang tidak mampu mengontrol segala kejadian yang sedang dialami dan merasa tidak berdaya atas banyak peristiwa. Menurut Seligman (2005) salah satu akibat dari learned helplessness adalah pengalaman yang berulang-ulang dengan kejadian-kejadian yang tidak dapat dikontrol akan mengarah pada perasaan tidak berdaya. Andin mengungkapkan bahwa alasan ia memutuskan pergi ke Kalimantan, selain iming-iming gaji, adalah untuk lari dari masalah keluarga yang tidak mampu diatasinya dan lari dari ketidakmampuannya melawan perlakuan buruk teman sekolahnya. Ia juga mudah "berhutang budi" atau tergantung dengan tawaran "pertolongan" yang menggiurkan dan figur Mami yang seolah mengurusi hidupnya. Rentetan kejadian yang tidak mampu dikontrolnya itulah yang mengakibatkan Andin mengalami learned helplessness dan pada akhirnya tidak dapat menolak ketika diminta untuk melayani pelanggan.

Pengalaman singkat menjadi pekerja seks karena ketidakberdayaan itu telah menimbulkan luka psikologis yang tidak mudah diatasi. Setelah saat ini Andin berhasil selamat dari kejahatan trafficking, ia terus berusaha keras untuk melupakan pengalaman masa lalunya sebagai korban. Dampak psikologis sebagai korban yang dialami Andin sebagian memiliki kesamaan dengan hasil penelitian Juwita (2008) terhadap Tenaga Kerja Wanita (TKW) yang menjadi korban kekerasan, yaitu merasa bersalah dan sedih jika teringat kejadian buruk di masa lalu dan merasa malu terhadap orang di sekitar hingga mengganggu hubungan sosial selanjutnya. Seiring dengan hasil analisis Gugus Tugas Nasional Pencegahan dan Penanganan Tindak
Pidana Perdagangan Orang (2009) tentang dampak yang dialami korban ttrafficking, penelitian ini juga berhasil mengungkap bahwa Andin mengalami perasaan bersalah dan berdosa yang meruntuhkan harga diri. Pada Andin, perasaan bersalah dan berdosa ini berada pada tingkat bahwa ia merasa kotor tidak layak dekat dengan Tuhan.

Dampak psikologis lain yang dialami Andin adalah merasa tak berdaya untuk mengubah diri menjadi lebih baik, tidak berhasil mengatasi pengalaman buruknya, dan merasa kehilangan kontrol atau perasaan tidak berdaya (Marliana, 2012). Hingga saat ini, Andin mencoba melupakan masa lalunya yang buruk dengan bergaul dan mencari hiburan bersama teman-teman kerjanya. Namun ia mengaku bahwa cara ini tidak berhasil. Ia tidak tahu mengapa tetap melakukannya. Tapi ia memiliki keyakinan bahwa pada akhirnya ia akan dapat berubah. Ia akan dapat mendekatkan diri dengan Tuhan, melepaskan ketergantungan pada temanteman yang saat ini bisa menjadi pelarian sementara, dan mampu menjaga nama baik keluarganya di mata masyarakat.

\section{SIMPULAN}

Berdasarkan pembahasan hasil penelitian di atas dapat disimpulkan bahwa remaja korban trafficking dalam bentuk eksploitasi seksual yang menjadi partisipan penelitian ini mengalami dinamika psikologis di antaranya adalah konsep diri negatif, rendahnya harga diri, dan learned helplessness. Dampak psikologis sebagai korban juga dialami antara lain perasaan sakit dan hancur ketika mengingat masa lalunya, rasa bersalah, rasa malu jika kisahnya diketahui, dan perasaan dirinya kotor serta penuh dosa hingga tidak pantas dekat dengan Tuhan.

Sebelum menjadi korban trafficking, subjek mengalami attachment yang kurang kokoh dengan orang tua maupun keluarganya 
yang mengakibatkan subjek mengalami tekanan emosional. Masalah dengan keluarga dan dengan teman-temannya di sekolah turut andil dalam membuat subjek melarikan diri dari rumah dan keluar dari sekolah. Situasi tersebut menjadi pintu awal subjek terjebak dalam kejahatan perdagangan manusia (human trafficking). Subjek juga cenderung mengembangkan konsep diri negatif akibat persepsinya bahwa keluarganya kurang memperdulikannnya dan cenderung menyalahkannya atas berbagai hal. Konsep diri negatif subjek membuatnya sulit mengembangkan hubungan sosial yang baik dengan teman-teman sebayanya di sekolah. Subjek juga mengembangkan harga diri yang rendah, dimana subjek merasa bahwa ia adalah orang yang lemah dan mudah diperdaya orang lain. Pengalaman ketidakmampuan mengontrol berbagai situasi sepanjang hidupnya melahirkan learned helplessness atau ketidakberdayaan subjek terhadap lingkungan yang membuat subjek menyerah atas situasi eksternal yang mengendalikannnya. Keadaan learned helplessness inilah yang pada akhirnya membuat subjek akhirnya terpaksa bersedia menjadi pekerja seks.

Namun, hasil internalisasi nilai-nilai moral yang diperoleh subjek sejak kecil membuat subjek tidak mampu mengatasi rasa bersalahnya karena bekerja sebagai pekerja seks. Rasa bersalah itulah yang mendorongnya untuk mencari jalan keluar dari situasi buruknya hingga akhirnya menemukan pertolongan. Saat ini subjek mencoba melupakan pengalaman buruknya sebagai korban dengan memfokuskan diri pada pekerjaan sebagai buruh pabrik dan pergaulan yang menyenangkan dengan teman-teman kerjanya. Meskipun demikian, ia tetap tidak bisa melupakan masa lalunya, merasa berdosa di hadapan Tuhan, dan merasa malu jika kisahnya terungkap. Ia tetap berusaha berubah dengan memperbaiki hubungannnya dengan Tuhan dan memperbaiki citra keluarganya di mata masyarakat sekitar.

\section{DAFTAR PUSTAKA}

Ardani, T. A., Rahayu, I. T., \& Solichatun, Y. (2007). Psikologi Klinis. Cet. Ke-1. Yogyakarta: Graha Ilmu.

Baron, R. A. \& Byrne, D. (2005). Psikologi Sosial. Jilid 2. Edisi Kesepuluh. Alih Bahasa: Ratna Djuwita dkk. Jakarta: Erlangga.

Emzir. (2011). Metodologi Penelitian Kualitatif: Analisis Data. Jakarta : Raja Grafindo Persada.

Farhana, T. (2010). Aspek Hukum Perdagangan Orang Di Indonesia. Jakarta: Sinar Grafika.

Fausiah, F. \& Julianti. W. (2005). Psikologi Abnormal Klinis Dewasa. Jakarta: Universitas Indonesia.

Gugus Tugas Nasional Pencegahan dan Penanganan Tindak Pidana Perdagangan Orang. (2009). Korban Perdagangan Manusia Membutuhkan Pendampingan yang Intensif. Diakses dari http://www. gugustugastrafficking.org/index.php?optio $n=$ com_content $\&$ view $=$ article $\& i d=2331$ : korban-perdagangan-manusiamembutuhkan-pendampingan-yangintensif\& catid $=77:$ info \& Itemid $=106$. pada 1 Juli 2013.

Hukumonline.com. (2012). LPSK Fokus Perdagangan Orang. Diakses dari: http://www.hukumonline.com/berita/baca/ lt4f7448e3a46cc/lpsk-fokus-perdaganganorang. pada 1 Juli 2013.

Juwita, R. (2008). Dampak Psikologis Pada TKW (Tenaga Kerja Wanita) Korban Kekerasan, (online). Diakses dari http://eprints. umm.ac.id/id/eprint/49431htm. pada tanggal 03 Maret 2013.

Kaplan, H. I., Sadock, B. J., \& Grebb, J. A. (2010). Sinopsis Psikiatri. Jilid II. (Edisi ke-7). Ahli 
Bahasa : Widjaja Kusuma. Jakarta : Binarupa Aksara.

Marliana, T. (2012). Kajian Tentang Pengalaman Hidup Perempuan Korban Trafficking dalam Perspektif Kesehatan Jiwa. Tesis: Program Magister Ilmu Keperawatan Kekhususan Keperawatan Jiwa Universitas Indonesia. Diakses dari: http://lontar.ui.ac.id/file?file $=$ digital $/ 2030$ 2848-T30656\%20-\%20Kajian\%20tentang .pdf. pada 21 Juli 2013.

Murray, M. (2009). Psikologi Naratif. Dalam J. A. Smith (ed). Psikologi Kualitatif: Panduan Praktis Metode Riset (hlm 219-257). Edisi terjemahan. Yogyakarta: Pustaka Pelajar.

Nasution, A. Z. (2008). Perlindungan hukum terhadap perempuan dan anak Korban perdagangan manusia (trafficking in persons), (online). Diakses dari http://eprints.undip.ac.id/17904/1/zaky_al kazar_nasution.pdf. pada 28 Januari 2013.

Pusat Pelayanan Terpadu Perlindungan Perempuan dan Anak/PPT-P2A. (2012). Jenis Kekerasan yang Ditangani di PPT Provinsi Jawa Timur. Surabaya: Tidak Dipublikasikan.

Rakhmat, J. (2009). Psikologi Komunikasi. Bandung: PT. Remaja Rosdakarya.

Saniti, N. A. (2013). Diagnosis dan Manajemen Stress Paska Trauma pada Penderita
Pelecehan Seksual. Diakses dari: http://download.portalgaruda.org/article.ph p article $=82548 \& \mathrm{val}=970$. pada 1 Juli 2013 .

Santrock, J. W. (2007). Remaja. Edisi 11. Jilid 1. Alih Bahasa: Benedictine Widyasinta. Jakarta: Erlangga.

Santrock, J. W. (1995). Life Span DevelopmentPerkembangan Masa Hidup. Edisi Kelima. Jilid I. Jakarta : Erlangga.

Seligman, M. E. P. (2005). Authentic Happiness: Menciptakan Kebahagiaan dengan Psikologi Positif. Bandung : PT Mizan Pustaka.

Sitompul, E. A. (2009). Gambaran Learned Helplessness Pada Supir Angkutan di Kota Medan Ditinjau Dari Explanation Style. ( o n $1 \mathrm{ine}$ ). D i a k s s d a r i http://repository.usu.ac.id/bitstream/12345 6789/14507/1/09E02914.pdf. pada 23 Juli 2013.

Smith, J. A. (2009). Psikologi Kualitatif Pamduan Praktis Metode Riset. Penerjemah: Budi Santoso. Yogyakarta: Pustaka Pelajar.

Wartakota. (2013, Juli 2013). UNFPA: Perdagangan manusia di Indonesia masuk peringkat 2 dunia. Di akses dari http://wartakota.tribunnews.com/2013/07/ 01/unfpa-perdagangan-manusia-diindonesia-masuk-peringkat-2-dunia, pada tanggal 21 Juli 2013. 